\title{
Persistence of Coumarins Rodenticidas Brodifacoum and Coumatetralyl in Brazilian Urban Environment
}

\author{
Solange Papini ${ }^{1}$, Rita de Cássia Boccuzzi Prisco ${ }^{2}$, Vera Lúcia Tedeschi Savoy ${ }^{2}$, \\ Eliane Vieira ${ }^{2}$, Luiz Carlos Luchini ${ }^{2}$ \\ ${ }^{1}$ City Hall of São Paulo, São Paulo, Brazil \\ ${ }^{2}$ Biological Institute, São Paulo, Brazil \\ Email: savoy@biologico.sp.gov.br
}

Received December 6, 2011; revised January 12, 2012; accepted February 16, 2012

\begin{abstract}
The chemical control of Rattus norvegicus in São Paulo city has been done using coumarins rodenticides as paraffin block and powder contact. The brodifacoum-paraffin block is placed in culverts and similar sites being subject to the action of the weather that can change the concentration of active ingredient. Whereas coumatetralyl-powder contact is applied on the entrance of the burrows, being subject to the action of the weather, that can help in the active ingredient degradation and its transference to other environments. There is not information on the environmental persistence of these active ingredients in their formulations after placing on the environment. So this research evaluated the persistence of brodifacoum-paraffin block and coumatetralyl-powder contact after two months under environmental conditions. One hundred blocks were put in culverts and weekly, during two months, three blocks were retreated and submitted to extraction and the extract analyzed by high performance liquid chromatography for quantification of active ingredient. The coumatetralyl-powder contact was applied in experimental systems simulating the field conditions. Soil and water samples were collected weekly, for two months, submitted to the extraction and the extracts analyzed by high performance liquid chromatography for quantification of active ingredient. The results pointed the stability of brodifacoum-paraffin block under real application environmental conditions because $100 \%$ of active ingredient was recovered after exposition of the blocks. However, there was decreased about $80 \%$ in the concentration of coumatetralylpowder contact on top soil during two months of environmental exposition, however there was not found it in water sample.
\end{abstract}

Keywords: Hydroxycoumarin; Rodenticide; Environmental Contamination

\section{Introduction and Purpose}

The environmental aspects of cities create conditions for the establishment and proliferation of synanthropic animals $[1,2]$ and some these animals are related with different human diseases [3-5]. The control of these animals can be done by three possible actions: orientation of the population, environmental management and the rodenticides use. The rodenticides seeking the immediate decrease of the population when there are large Infestations $[1,6]$. But, must be remembered that use these products can contaminate the urban environment, eliminate noninjurious species, some theirs predators of pests, and

\footnotetext{
${ }^{*}$ This work is part of project evaluation of the dissipation in the environment rodenticides hidroxicumarínicos formulations pellet, powder and paraffin block used for desratization, developed with funding Fundação de Amparo à Pesquisa do Estado de São Paulo (FAPESP no. 05/53829-6).
}

contribute to development of resistance to the inputs utilized. In addition can occur degradation of the compounds in substances more toxics and so to cause intoxication and contamination of the non-target organisms [7].

In the control of $R$. norvegicus, specie related at transmission of leptospirosis to mankind with active ingredient (a.i.) brodifacoum: 3-(3-(4'-bromobiphenyl-4-yl)-1,2,3,4tetrahydro-1-naphthyl)-4-hydroxycoumarin (see Figure 1) in the formulation paraffin block is very utilized, because usually it lives under the soil, digging tunnels an burrows and breeding in these sites [8]. So, it is frequent your circulation in the storm drains and rainwater, ground soil phone box and margins of streams, preferring sites near to source of the food and water [2]. The paraffin blocks are placed in culverts and similar sites, fixed by wire to how do not stay in contact with the water and same time permit that the animal has accessed and eat the bait. The 
blocks are in this site until the animal eats them that not always occur. Sometimes, after many days or weeks, the blocks are still in site. The a.i. brodifacoum is little water soluble and stable to hydrolysis and when in water solution is degraded under ultraviolet radiation [9].

Also is used in control of $R$. norvegicus the coumatetralyl (see Figure 2) formulated as powder contact applied in the entrance of burrows to that the animals have the adhered product their bodies and ingested the rodenticide when cleaning themselves [6].

The active ingredient coumatetralyl \{4-hydroxy-3-[(1RS)1,2,3,4-tetrahydro-1-naphthyl]coumarin \} is soluble in some organic solvents and degrades faster in water solution exposed to ultraviolet light with half life about 1 hour [9].

Both a.i. brodifacoum and coumatetralyl have coefficient partition and octanol-water and bioaccumulation factors that suggest high bioconcentration potential, but it has low mobility in soil and they present low volatility [9].

There is information about stability of these active ingredients in appropriate storage conditions, but when the formulated products are placed in environment there are not informations about their persistence. This research evaluated the persistence of a.i. brodifacoum and coumatetralyl formulated as paraffin block and powder contact, respectively, after 2 months in the use conditions environmental.

\section{Materials and Methods}

\subsection{Reagents and Solutions}

The brodifacoum $99.5 \% \mathrm{~m} / \mathrm{m}$ and coumatetralyl $99.9 \%$ $\mathrm{m} / \mathrm{m}$, both acquired from Interprise Chemical, were used in the establishment of analytical conditions for high performance liquid chromatography (HPLC) and commercial products ROGAMA, paraffin block-brodifacoum and powder contact-coumatetralyl, were used in field<smiles>O=c1oc2ccccc2c(O)c1C1CC(c2ccc(-c3ccc(Br)cc3)cc2)Cc2ccccc21</smiles>

Figure 1. Brodifacoum.<smiles>O=c1oc2ccccc2c(O)c1C1CCCc2ccccc21</smiles>

Figure 2. Coumatetralyl. tests.

\subsection{Apparatus}

Instrument HPLC Dionex; UV/VIS Detectors UVD170U/ 340U; HPLC pumps P680; column compartment TCC100; software Chromeleon 6.

\subsection{Samples Treatments}

One hundred of paraffin blocks brodifacoum were placed in culverts previously desratized in December and left by two months. Weekly three samples were randomly retreated of the culverts to extraction of $8.0 \mathrm{~g}$ with $25.0 \mathrm{~mL}$ of methanol + dichloromethane + acetic acid $(9+0.75+$ 0.25 ) for $1 \mathrm{~h}$ at $40^{\circ} \mathrm{C}$ under ultrasonic agitation. The extracts were filtrated by filter paper $(2.0 \mathrm{um})$ and submitted to analysis by HPLC for detection and quantification of active ingredient. The a.i. presence in each sample was presented as percentage the detected at not-exposed blocks analyzed $\left(\mathrm{T}_{\text {zero }}\right)$.

Twenty grams of powder contact coumatetralyl were applied on clay-soil layer with about $2 \mathrm{~g}$ soil in 33 systems under controlled exposure in outer area of Instituto Biológico. This application corresponds to $60.0 \mathrm{mg}$ a.i. $\mathrm{g}^{-1}$ soil, concentration confirmed from analysis of soil samples. Each system were a polyvinyl chloride pipe with 25 $\mathrm{cm}$ diameter and filled with soil to a height of $5 \mathrm{~cm}$ to enable the percolation of rainwater collected glass bottle with a capacity of 4 liters. Environmental conditions, rainfall and temperature were monitored using rain gauge and maximum and minimum thermometer, placed at the experimental site. Weekly the soil of three systems randomly were removed to extraction of $30 \mathrm{~g}$ with $50.0 \mathrm{~mL}$ distilled water under $30 \mathrm{~min}$ mechanical agitation and so added $50.0 \mathrm{~mL}$ acetonitrile under $30 \mathrm{~min}$ mechanical agitation. After filtration filter paper $(2.0 \mu \mathrm{m})$ the extracts were submitted to analysis by HPLC for detection and quantification of a.i. Samples with $10.0 \mathrm{~mL}$ of percolated rainwater collected were subjected to extraction liquid-liquid with $50.0 \mathrm{~mL}$ dichloromethane and the extracts analyzed by HPLC. The a.i. presence in each sample, soil and water, was presented as percentage the detected at soil of 3 systems soon after application powder contact $\left(\mathrm{T}_{\text {zero }}\right)$.

\subsection{HPLC Conditions}

Brodifacoum determination: wavelength $260 \mathrm{~nm}$; notpolar column phase octadecyl-silica RP-18 (250 mm $\times$ $46 \mathrm{~mm}$ ); work temperature $22^{\circ} \mathrm{C}$; mobile phase methanol: water: glacial acetic acid $(88.5: 10: 1.5)$; flow $1 \mathrm{~mL} \cdot \mathrm{min}^{-1}$ [10].

Coumatetralyl determination: wavelength $254 \mathrm{~nm}$; nonpolar column phase octadecyl-silica RP-18 (250 mm $\times$ 
$46 \mathrm{~mm}$ ); work temperature $22^{\circ} \mathrm{C}$; mobile phase methanol: $\mathrm{H}_{3} \mathrm{PO}_{4} 1 \%$ (75:25); flow $1.0 \mathrm{~mL} \cdot \mathrm{min}^{-1}$ [11].

\section{Results}

The HPLC calibration curve brodifacoum (see Figure 3) was linear between 1.25 and $10.0 \mu \mathrm{g} \cdot \mathrm{mL}^{-1}$, correlation coefficient (r) 0.99, determination coefficient $\left(\mathrm{r}^{2}\right) 0.99$ and retention time $11.8 \mathrm{~min}$. The HPLC calibration curve coumatetralyl (see Figure 4) showed linearity between 5.0 and $60.0 \mu \mathrm{g} \cdot \mathrm{mL}^{-1}$, correlation coefficient (r) 0.99 , determination coefficient $\left(\mathrm{r}^{2}\right) 0.99$ and retention time 7.5 $\min$ (see Figures 3 and $\mathbf{4}$ ). The limits of detection (LOD) and quantification (LOQ) of the methods were established statistically by regression analysis with $95 \%$ confidence limit: brodifacoum $\mathrm{LOD}=0.31 \mu \mathrm{g} \cdot \mathrm{mL}^{-1}$ and $\mathrm{LOQ}=0.61$ $\mu \mathrm{g} \cdot \mathrm{mL}^{-1}$; coumatetralyl LOD $=1.92 \mu \mathrm{g} \cdot \mathrm{mL}^{-1}$ and LOQ $=$ $3.76 \mu \mathrm{g} \cdot \mathrm{mL}^{-1}$.

The results of HPLC-analyze showed there was no significant change in the a.i. brodifacoum concentration after two months (see Table 1).

It was observed decrease in the coumatetralyl concentration over the two months of environmental exposure (see Table 2). In the first week (T1) was recovered 37.7 $\mu \mathrm{g}$ a.i $\pm 4.2 \mathrm{~g}^{-1}$ soil and in the eighth week (T8) was recovered $12.4 \mu \mathrm{g}$ a.i. $\pm 1.6 \mathrm{~g}^{-1}$ soil (Table 2). So there was a reduction of about $40 \%$ in the a.i. concentration between the first and the eighth week. Although, the coumatetralyl has been present in top soil, it was not detected in the water sample percolating through the soil.

\section{Discussion}

The stability in the brodifacoum concentration after two months was probably due to the conditions where were placed the blocks. The temperature variation into culverts was smaller than ambient temperature that varied between $15^{\circ} \mathrm{C}-19^{\circ} \mathrm{C}$ (minimum temperature) and $24^{\circ} \mathrm{C}$ $34^{\circ} \mathrm{C}$ (maximum temperature), because there is little light at this place end the temperature is not so variable. Moreover into culverts there were many organic and inorganic residues that can have stayed on the blocks protect them of direct light and water. These characteristics can have contributed to reduce the degradation of the active ingredient.

In the tests with coumatetralyl-powder contact, the decrease can be related with uniform distribution of the product on the entrance of burrows because there is greater product surface exposure to light incidence and rain water. It is important highlight that the coumatetralyl can be degraded by photo degradation [9].

It is interesting to observe that after third week (T3)

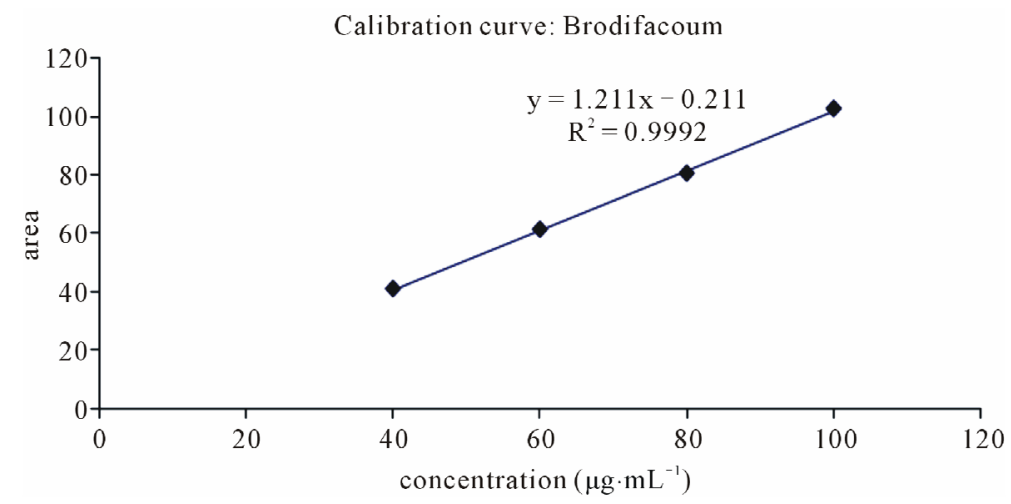

(a)

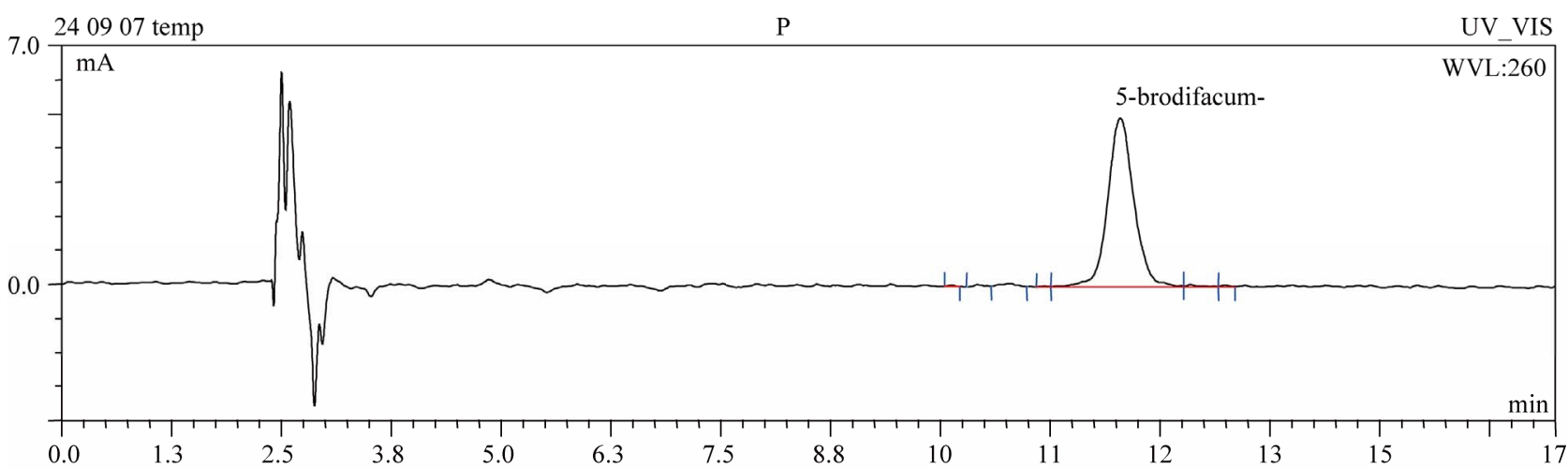

(b)

Figure 3. Brodifacoum calibration curve (a) and retention time (b). 


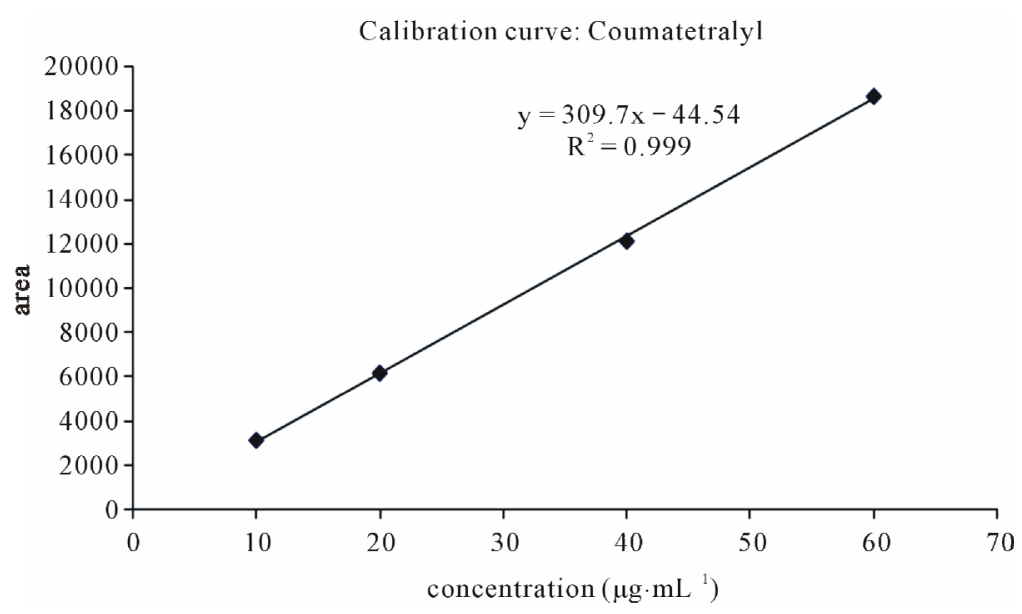

(a)

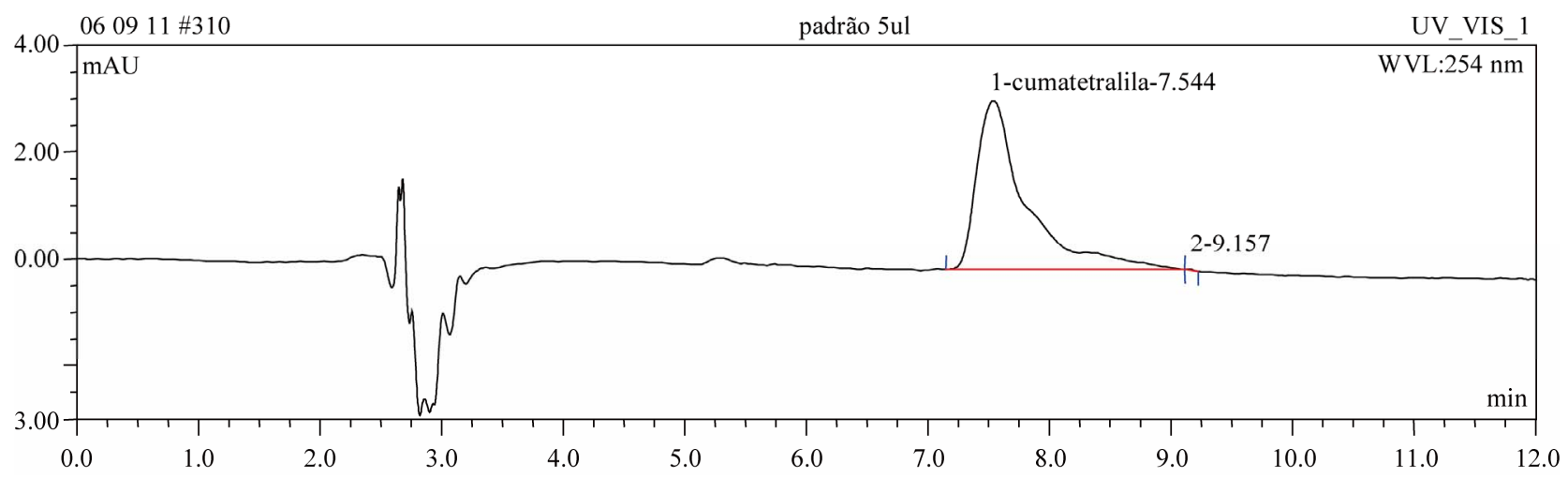

(b)

Figure 4. Coumatetralyl calibration curve (a) and retention time (b).

Table 1. Percentage of brodifacoum present in paraffin blocks at the beginning of the experiment and during the eight weeks of exposure.

\begin{tabular}{ccc}
\hline Week & Brodifacoum (\%) in paraffin blocks & CV (\%) \\
\hline $\mathrm{T}_{\text {zero }}$ & $103.23 \pm 6.83$ & 6.61 \\
$\mathrm{~T} 1$ & $101.57 \pm 0.44$ & 0.43 \\
$\mathrm{~T} 2$ & $102.15 \pm 4.32$ & 4.23 \\
$\mathrm{~T} 3$ & $104.05 \pm 6.85$ & 6.58 \\
$\mathrm{~T} 4$ & $101.48 \pm 4.36$ & 4.29 \\
$\mathrm{~T} 5$ & $104.22 \pm 7.58$ & 7.27 \\
$\mathrm{~T} 6$ & $99.42 \pm 5.38$ & 5.41 \\
$\mathrm{~T} 7$ & $99.00 \pm 6.05$ & 6.11 \\
$\mathrm{~T} 8$ & $107.87 \pm 3.39$ & 3.14 \\
\hline
\end{tabular}

even though no longer the product has been observed on the soil the coumatetralyl was detected and quantified. This fact showed that the absence of powder contact on soil does not ensure the absence of a.i. The people do not see the powder contact on soil can manipulate this soil
Table 2. Concentration of coumatetralyl after application of the product and within two months of study.

\begin{tabular}{cc}
\hline Week & Coumatetralyl $\left(\mu \mathrm{g} \cdot \mathrm{ai} \cdot \mathrm{g}^{-1}\right.$ soil $)$ \\
\hline $\mathrm{T}_{\text {zero }}$ & $56.66 \pm 5.66$ \\
$\mathrm{~T} 1$ & $37.66 \pm 4.17$ \\
$\mathrm{~T} 2$ & $36.65 \pm 1.22$ \\
$\mathrm{~T} 3$ & $28.81 \pm 1.60$ \\
$\mathrm{~T} 4$ & $26.87 \pm 3.98$ \\
$\mathrm{~T} 5$ & $13.76 \pm 2.04$ \\
$\mathrm{~T} 6$ & $11.20 \pm 2.86$ \\
$\mathrm{~T} 7$ & $11.09 \pm 2.22$ \\
$\mathrm{~T} 8$ & $12.41 \pm 1.61$ \\
\hline
\end{tabular}

and exposed themselves to the toxic compound. On the other hand, the rats to pass this way may be intoxicated and thus the product turns out to have prolonged its effectiveness in the environment. This aspect is important in the control of rodents.

The percentage of active ingredient in the third (T3) 
and fourth (T4) weeks were $49.7 \% \pm 3.2 \%$ and $44.8 \% \pm$ $5.9 \%$, respectively, showing that between $40.0 \%$ and $50.0 \%$ a.i. was dissipated from surface soil. However in the fifth (T5) and sixth (T6) weeks the percentage of active ingredient was a marked decrease, $26.3 \% \pm 5.2 \%$ in T5 and $26.8 \% \pm 5.0$ in T6. In these two weeks were a lot of rains, 154 and $103 \mathrm{~mm}$, respectively, which may have favored the hydrolysis of coumatetralyl.

Although the a.i. concentration had decreased after 2 months, it was still possible detect and quantify the coumatetralyl in the soil. This fact deserves attention because this rodenticide is periodically applied in places with poor sanitary and environmental conditions, as banks of streams and often irregular housing for lowincome population. In these places, in general, there is no system of water supply or sewage collection and often regular garbage collection.

The environmental persistence can be risk to the population, especially children that are in direct contact with soil in parks and squares. Also some pesticides can be absorbed by its roots and distributed to all plant tissues, accumulating in different organs although we have not encountered this phenomenon with coumatetralyl rodenticide [12], but it is a possibility that should be considered. Moreover is important highlight that chemicals use can be potential risk environmental contamination and bioaccumulation. The organisms living in soil or sediments are directly exposed and can bioaccumulate the compounds in their tissues [13].

Moreover, as are made repeated applications of coumatetralyl-powder contact, the presence even after 2 months must be preceded care because this a.i. persists in the environment after two months, although in low concentration.

The tests with water sample percolating through the soil did not show the presence of coumatetralyl so this a.i. was not leached through the soil, being retained in the surface layer where it can be degraded by physical, chemical or biological process. These results showed a low risk of groundwater contamination. Although coumatetralyl has not been strongly adsorbed to organic carbon and clay soil [11] the use of clay soil may have hindered the leaching of the product due to less space available for the motion of particles. As in the sandy soils there are greatest aeration and transport of water and nutrients due to the more spacing between the particles [14], it is possible occurrence of leaching.

Although coumatetralyl and brodifacoum are different active ingredients, both are hydroxycoumarins with many physical and chemical characteristics in common $[14,15]$. So, the longest persistence time of brodifacoum was probably due to its formulation, paraffin block, and application methodology. While the active ingredient formulated as a powder coumatetralyl contact, placed on the soil in the entrance of the burrows of rodents, is exposed to solar radiation and extreme temperature changes.

\section{Conclusions}

There was decreased in the concentration of the coumatetralyl-powder contact on topsoil over 2 months, although the product has been detected in the eighth week, but there was no leaching of the compound.

About $10 \%$ of a.i. coumatetralyl formulated as powder contact remained in the topsoil during eight weeks after product application.

The brodifacum paraffin block showed low environmental temperature resistance.

The concentration of brodifacoum-paraffin block had not decreased paraffin block during 2 months of culverts environmental exposure, but decreased in controlled systems during eight weeks of exposure.

\section{REFERENCES}

[1] S. Papini, "Vigilância em Saúde Ambiental: Uma Nova Era da Ecologia,” Editora Atheneu, São Paulo, 2008.

[2] E. De Masi, P.Vilaça and M. T. P. Razzolini, "Environmental Conditions and Rodent Infestation in Campo Limpo District, São Paulo Municipality, Brazil," International Journal of Environmental Health Research, Vol. 19, No. 5, 2009, pp. 1-16. doi:10.1080/09603120802126670

[3] FUNASA, "Manual de Saneamento,” No. 4, Brasília, 2006, pp. 293-295.

[4] FUNASA, "Manual de Saneamento,” No. 4, Brasília, 2006, pp. 319-322.

[5] L. H. Krøjgaard, S. Villumsen, M. D. Markussen, J. S. Jensen, H. Leirs and A. C. Heiberg, "High Prevalence of Leptospira spp. in Sewer Rats (Rattus norvegicus)," Epidemiology \& Infection, Vol. 137, No. 11, 2009, pp. 15861592. doi:10.1017/S0950268809002647

[6] FUNASA, "Manual de Controle de Roedores," Brasília, 2006, pp. 67-73.

[7] L. C. Luchini and M. M. Andrea, "Dinâmica de Agrotóxicos no Ambiente," In: Fórum Nacional de Secretários, Programa de Defesa Ambiental Rural-Textos Orientadores, Brasília, 2002, pp. 27-44.

[8] M. R. Potenza and F. J. Zorzenon, "Baratas e Roedores," In: F. J. Zorzenon and J. Justi, Eds., Manual Ilustrado de Pragas Urbanas e Outros Animais Sinantrópicos, Instituto Biológico, São Paulo, 2006, pp. 139-145.

[9] C. R. Worthing and R. Hance, "The Pesticide Manual," The British Crop Protection Council, Surrey, 1991, pp. 188-189.

[10] S. Papini, R. C. B. Prisco, L. C. Luchini, V. L. T. Savoy, E. Vieira and L. E. Nakagawa, "Avaliação da Dissipação no Ambiente do Raticida Brodifacum Formulado Como Bloco Parafinado," Pesticidas: Revista de Ecotoxicologia e Meio Ambiente, Vol. 19, 2009, pp. 39-48.

[11] S. Papini, R. C. B. Prisco, L. C. Luchini and V. L. T. 
Savoy, "Comportamento Ambiental do Raticida Cumatetralila em Pó de Contato: Importância na Saúde Pública," Pesticidas: Revista de Ecotoxicologia e Meio Am-biente, 2008, Vol. 18, pp. 83-94.

[12] A. Doshi and B. B. L. Thakore, "Uptake Translocations and Residues of Metalaxyl in Opium Plants," Indian Journal Plant Protect, Vol. 23, 1995, pp. 191-194.

[13] M. J. B. Amorim, J. P. Sousa, J. A. Nogueira and A. M. V. M. Soares, "Bioaccumulation and Elimination of ${ }^{14} \mathrm{C}$ -
Lindane by Enchytraeus albidus in Artificial (OECD) and a Natural Soil," Chemosphere, Vol. 49, No. 3, 2002, pp. 323-329.

[14] L. Prado, "Solos do Brasil," Escola Superior de Agronomia Luiz de Queirós, Piracicaba, No. 3, 2003, pp. 12-20.

[15] C. R. Worthing and R. Hance, "The Pesticide Manual," The British Crop Protection Council, Surrey, 1991, pp. 91-92. 